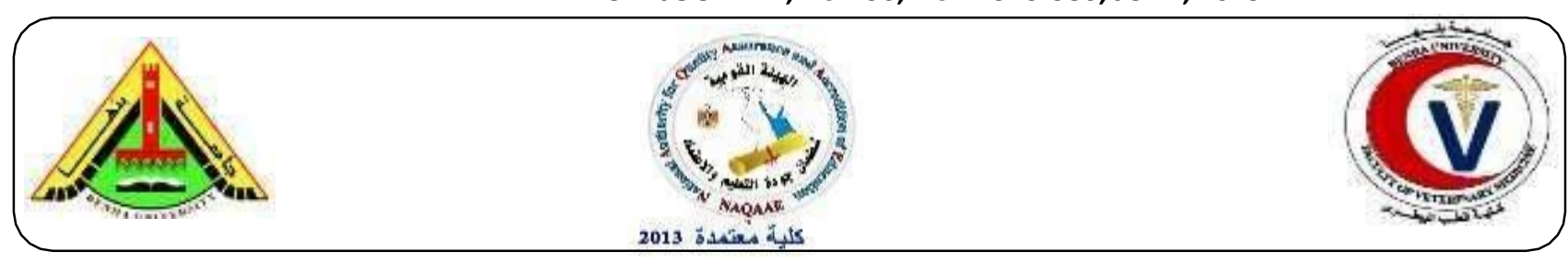

\title{
Effect of using synbiotics and essential oils on performance parameters and immune response of necrotic enteritis challenged broiler chicks.
}

\author{
Amal, H. T. Abdelnaser; Magda, M. A. Moustafa and Marwa, I. Abd El-Haleem \\ Department of Avian and Rabbit Diseases, Faculty of Veterinary Medicine, Benha University
}

\section{A B S T R A C T}

One hundred and eighty healthy one-day-old broiler chicks were used to evaluate the effect of synbiotics and/ or essential oils (EO) as alternatives to antibiotics on performance in induced necrotic enteritis (NE) and immunity. EO treatment improved the total feed conversion ratio (FCR) in comparison with challenged non-treated group and antibiotic treated group. While using synbiotics did not ameliorate the negative impact of necrotic enteritis challenge on feed intake and FCR. The treatments had positive impact on immune response to vaccination against Newcastle disease (ND), infectious bronchitis (IB), avian influenza (AI) and infectious bursal disease (IBD) as well as they increased the spleen relative weight. The synbiotic treatment alleviate the histopathological changes from vaccination in bursa of Fabricius (BF) as well as antibiotic treated group. The results suggest that EO and synbiotics, as replacements to antibiotics, may be an effective tool to augment performance and immune response of NE challenged birds.

Keywords: Necrotic enteritis, performance, Synbiotics, immunity, Essential oils, broilers.

(http://www.bvmj.bu.edu.eg)

(BVMJ-36(2): 373-380, 2019)

\section{INTRODUCTION}

Antibiotics have been common feed additive in poultry rations as they were frequently used for prophylaxis against diseases in birds (Sun et al., 2005). The continued feeding of antibiotics at subtherapeutic levels caused imbalance of gut microflora, antibiotic residue and developed drug-resistant bacteria (Jensen, 1998 and Andremont, 2000)]. Consequently, the Europe Union Commission banned antibiotics in animal feeds since 2006 (Europe Union Commission, 2005). Nevertheless, several countries implied to banning suffered from rearise of necrotic enteritis outbreaks in broilers (Van Immerseel et al., 2004).

Necrotic enteritis is an enterotoxemic multifactorial disease that destroys the intestinal lining of the digestive tract of both wild and domestic birds especially chickens used for meat production all over the world. Some toxins secreted from $C$. perfringens types $\mathrm{A}$ and $\mathrm{C}$ are incriminated in the necrotic lesions in the intestinal wall and mortalities which in turn leads to high economic losses estimated to be more than $\$ 3$ billion/ year (Jayaraman et al., 2013).

The use of dietary additives as synbiotics and phytobiotics is gaining momentum and paid an attention to be used as alternatives to antibiotics because of their beneficial effects on performance and gut microflora (Mitsch et al., 2004 and Dahiya et al., 2006).

Synbiotics are mixture of probiotics and prebiotics that beneficially affect the host by improving the survival and implantation of live microbial dietary supplements in the gastrointestinal tract by selectively stimulating the growth and / or activating the metabolism of one or a limited number of health promoting bacteria, and hence improving host welfare (Fooks and Gibson, 2002). 
The phytobiotics are natural new class of additives that based on herbs, spices and fruits. Essential oils, as a category of phytobiotics, are volatile lipophilic compounds derived by cold expression or by steam or alcohol distillation (Khan, 2014). They enhance the productivity through improvement of digestibility, nutrient absorption and elimination of pathogens in the gut as well as, they have a high acceptability among consumers (Kubkomawa et al., 2013).

The goal of this work is to evaluate the potential protective effects of synbiotic, essential oils and their combination as alternatives to antibiotic feed additives on performance and immunity in the NE challenged broiler chicken.

\section{MATERILAS AND METHODS}

\subsection{Birds and management:}

The present experiment conducted on 180, healthy one-day-old broiler chicks (Arbor Acres). Birds fed on well-balanced diet (Table 1) formulated according to (NRC, 1994). They were housed in a clean disinfected wellventilated room $(5 \mathrm{~m} \times 7 \mathrm{~m})$. The room divided into 5 equal partitions for the first five groups (G1 - G5). The control group (G6) housed in a separate place. The rooms provided with suitable number of heaters, feeders and drinkers.

\subsection{Experimental design:}

The experimental birds were randomly divided into 6 groups ( 30 birds/3 replicates / group). 1, Antibiotic and anti coccidia (ABAC) group: challenged with Eimeria spp. $+C$. perfringens and fed basal diet with chlortetracycline $\mathrm{Hcl}$ at rate $1 \mathrm{~kg}$ / ton (Atco pharma) and diclazuril at rate $200 \mathrm{gm} /$ ton (Atco pharma); 2, Synbiotic (SY) group: challenged with Eimeria spp. $+C$. perfringens and fed basal diet with synbiotic based on Bacillus subtilis, B. licheniformis, Saccharomyces cerevisiae, beta glucan and mannanoligosccharides at rate $250 \mathrm{gm} / \mathrm{ton}$ (organic chemical solutions, L.L.C. - USA); 3, Essential oils (EO) group: challenged with Eimeria spp. $+C$. perfringens and fed basal diet with essential oils of oregano, anise, and citrus peel at rate of $125 \mathrm{gm} / \mathrm{ton}$ (BIOMIN Singapore Pte Ltd); 4, Synbiotic and essential oils (SYEO) group: challenged with Eimeria spp. $+C$. perfringens and fed basal diet with combination of synbiotics and essential oils at same doses mentioned before; 5, Necrotic enteritis (NE) group: fed basal diet and challenged with Eimeria spp. + C. perfringens and 6, CN group (control negative): fed basal diet only. The SY and SYEO groups were sprayed at hatchery by probiotic based on $5 \times 10^{12} \mathrm{CFU}$ of Enterococcus spp., Bifidobacterium spp., Pedicoccus spp. and Lactobacillus spp. (BIOMIN Singapore Pte Ltd) at rate of $20 \mathrm{gm} /$ 1000 bird. Experimental birds fed diet with additives from zero to 35 days of age and vaccinated against $N D, I B, A I$ and $I B D$ as shown in table (2).

\subsection{Experimental induction of $N E$ :}

The induction of necrotic enteritis was done according to Gholamiandehkordi et al., (2007). At $12 \mathrm{~d}, 10$-fold dose of commercial live attenuated coccidia vaccine (Coccivac $\mathrm{B}^{\mathrm{TM}}$ Schering plaugh animal health) based on $E$. acervulina, E. maxima, E. Necatrix and E. tenella given orally to birds of groups 1 to 5 to mimic the detrimental effect of coccidiosis. At 14 days ; the same groups were given $10^{5}$ of intermediate IBD virus (Cevac ${ }^{\mathrm{TM}}$ Gumbol Ceva). At 17 days the birds of groups 1-5 were orally challenged once daily for three successive days by $1 \mathrm{ml}$ of $4 \times 10^{8} \mathrm{CFU} / \mathrm{ml}$ of type A $\alpha$-toxigenic field strain of $C$. perfringens that obtained from the department of anaerobes; Veterinary Serum and Vaccines Research Institute in Abbasia.

\subsection{Performance parameters: \\ 2.3.1.Feed intake (FI):}

The FI calculated weekly by dividing the amount of feed consumed in grams (by a certain group) by the number of chicks of this group during the same week.

\subsubsection{Feed conversion ratio $(F C R)$ :}

Feed conversion ratio calculated weekly according to Lambert et al., (1936) by the following equation:

$$
\mathrm{FCR}=\frac{\text { Average feed intake }(\mathrm{g}) \text { bird/week }}{\text { Average body weight gain }(\mathrm{g})}
$$

\subsection{Humeral immune response to viral vaccines:}

Antibody titers against ND and AI vaccination were measured twice at $3^{\text {rd }}$ and $5^{\text {th }}$ weeks of 
experiment by haem agglutination inhibition (HI) test according to OIE, (2012).

Antibody titer against IB and IBD vaccination were measured twice at $3^{\text {rd }}$ and $5^{\text {th }}$ weeks of experiment by using specific ELISA kits in accordance with the protocols specified by the OIE, (2012).

\subsection{The relative weight of immune organs:}

Bursa of Fabricius (BF), thymus and spleen were harvested from the euthanized birds at 23 day of age. These organs were weighed and their relative weights were calculated as organ weight/live BW×100 (Verma et al., 2004).

\subsection{Histopathological examination:}

Bursa of Fabricius and thymus were collected at $23 \mathrm{~d}$ of age and preserved in $10 \%$ formalin solution and examined according to Bancroft et al., (1996).

\subsection{Statistical analysis:}

Differences between groups were analyzed by using One-Way ANOVA and Duncan's multiple comparison Post Hoc tests (Duncan, 1955).

Table 1: Composition of starter, grower and finisher diets.

\begin{tabular}{llll}
\hline Ingredients & $\begin{array}{c}\% \\
\text { Grower }\end{array}$ & Finisher \\
\hline Yellow corn & 53.85 & 58.40 & 61.24 \\
Soyabean meal 47 & 34.6 & 28.70 & 28.70 \\
Corn gluten meal & 4.15 & 5.00 & 1.65 \\
Vegetable oil & 2.50 & 3.40 & 4.40 \\
Sodium chloride & 0.30 & 0.30 & 0.30 \\
DL-Methionine & 0.27 & 0.25 & 0.23 \\
L-Lysine & 0.22 & 0.35 & 0.12 \\
Limestone & 1.90 & 3.40 & 1.55 \\
mono-calcium phosphate & 1.43 & 1.20 & 1.10 \\
Sodium bicarbonate & 0.18 & 0.17 & 0.17 \\
Vitamins and mineral premix & 0.30 & 0.30 & 0.30 \\
\hline
\end{tabular}

Table 2: Vaccination programme.

\begin{tabular}{|c|c|c|c|c|}
\hline Age & Type of vaccine & Type and dose & Route & Company \\
\hline $7 d$ & $\begin{array}{l}\text { Cevac }^{\mathrm{TM}} \text { BIL } \\
(\text { Hitchner+ IB) }\end{array}$ & Live $-10^{9} /$ bird & Eye drop & Ceva \\
\hline $10 \mathrm{~d}$ & $\begin{array}{l}\text { Avian influenza (Subtype } \\
\qquad \mathrm{H}_{5} \mathrm{~N}_{2}-\mathrm{N} 28 \text { strain) }\end{array}$ & Inavtivated $-10^{7} /$ bird & $\mathrm{S} / \mathrm{C}$ & $\begin{array}{c}\text { QYH- Biotech } \\
\text { limited }\end{array}$ \\
\hline $14 d$ & $\begin{array}{l}\text { Cevac }{ }^{\mathrm{TM}} \text { Gumbol } \\
\text { (IBD-intermediate) }\end{array}$ & Live $-10^{5} /$ bird & Eye drop & Ceva \\
\hline
\end{tabular}

\section{RESULTS}

\subsection{Performance parameters:}

During the third week all treated groups showed significant decrease in FI in comparison with the $\mathrm{CN}$ group, while there was non significant difference in FCR of challenged groups either treated or not when compared with the $\mathrm{CN}$ group (Table 3 ). In addition, At the end of the experiment, all challenged groups either treated or not recorded non significant difference when 
compared to the $\mathrm{CN}$ group in TFI except the ABAC group (the highest value as $3.27 \mathrm{Kg}$ ) and in TFCR except the SY group ( the worst value; 2.59).

\subsection{Humeral immune response to vaccination:}

The HI antibody titer against ND and AI vaccines shown as $\log 10$ in table (4). A significant higher titer $(\mathrm{P}<0.05)$ was recorded in EO and SYEO groups at $3^{\text {rd }}$ week (1.11 and 1.10 respectively) in comparison with $\mathrm{NE}$ and $\mathrm{CN}$ groups (0). The antibody titer disappeared in serum of experimental chicks at $4^{\text {th }}$ and $5^{\text {th }}$ week of experiment except for the ABAC group, which showed 0.70 titer in $5^{\text {th }}$ week. The HI antibody titer against AI vaccine in SYEO and $\mathrm{ABAC}$ group was 0.30 at $3^{\text {rd }}$ week and this was lower than NE group (0.67). A significant high titer $(\mathrm{P}<0.05)$ was recorded in EO group (1.42) in comparison with NE group (1.10) at $5^{\text {th }}$ week of experiment. The recorded improvement was insignificantly higher than titer recorded in ABAC group (1.20) ( $\mathrm{P}>0.05)$.

At $3^{\text {rd }}$ and $5^{\text {th }}$ week of the experiment ELISA antibody titer against IB vaccine was significantly higher $(\mathrm{P}<0.05)$ in $\mathrm{SY}$ group (4385and 13772 respectively) than NE group (117 and 9101.3 respectively) and ABAC group ( 0 and 4344 respectively). At $3^{\text {rd }}$ week, the titer in EO group was higher (2543.3) than NE group (117) and ABAC group (0) $(\mathrm{P}>0.05)$. The used biological treatments showed insignificant low antibody titer against IBD (634.67, 808.33 and 644.33 respectively) in comparison with $\mathrm{NE}$ group (922.33) at $3^{\text {rd }}$ week $(\mathrm{P}>0.05)$. In addition, the ABAC group showed significantly lower titer (233) in comparison with NE group $(\mathrm{P}<0.05)$. The antibody titer of EO group was significantly increased at $5^{\text {th }}$ weeks (293.33) in comparison with $\mathrm{NE}$ and ABAC groups (0) $(\mathrm{P}<0.05)$. Also, a significant increase in titer $(\mathrm{P}<0.05)$ was recorded in SYEO group (220) in comparison with NE group.

\subsection{Relative weight of immune organs:}

As shown in table (3), there was mild numerical fluctuation in relative bursal weight between treated birds and +ve challenge group. The ABAC group showed the highest bursal weight (0.14) while, the SY group showed the lowest weight ratio (0.08). The SY, EO and SYEO groups did not improve the relative thymus weight $(0.42,0.33$ and 0.38$)$ in comparison with $\mathrm{CN}$ and $\mathrm{ABAC}$ groups $(0.58$ and 0.46 respectively). The relative weight of spleen in The NE group showed lower relative spleen weight $(0.10)$ in comparison with $\mathrm{CN}$ group (0.14) $(\mathrm{P}>0.05)$. The relative weight of spleen was significantly increased in SYEO group $(0.15)(\mathrm{P}<0.05)$ while, $\mathrm{SY}$ and $\mathrm{EO}$ groups showed improvement in its relative weight (0.13 and 0.12) in comparison with $\mathrm{NE}$ and ABAC groups (0.09) $(\mathrm{P}>0.05)$.

\subsection{Histopathological findings:}

The BF of SY group showed mild histopathological alterations same as ABAC group in comparison with $\mathrm{NE}$ group and other treatments that showed moderate histopathological changes (Plate 1). The thymus of SY and EO groups showed mild histopathological alterations as hemorrhages and depletion of medullary thymocytes (Plate 2), the same degree of lesions shown in NE group, while the $\mathrm{ABAC}$ group showed the least degree of histopathological alteration.

Table 3: Effect of antibiotic, synbiotic and essential oils on performance parameters and relative weight of immune organs (means $\pm \mathrm{SE}$ ).

\begin{tabular}{lcccccc}
\hline & ABAC & SY & EO & SYEO & NE & CN \\
\hline FI $3^{\text {rd }} \mathrm{w}$ & $0.44 \pm 0.02^{\mathrm{b}}$ & $0.44 \pm 0.01^{\mathrm{b}}$ & $0.41 \pm 0.01^{\mathrm{b}}$ & $0.42 \pm 0.02^{\mathrm{b}}$ & $0.42 \pm 0.02^{\mathrm{b}}$ & $0.54 \pm 0.06^{\mathrm{a}}$ \\
Total FI & $3.27 \pm 0.25^{\mathrm{a}}$ & $2.69 \pm 0.02^{\mathrm{b}}$ & $2.78 \pm 0.19^{\mathrm{ab}}$ & $2.53 \pm 0.16^{\mathrm{b}}$ & $2.61 \pm 0.05^{\mathrm{b}}$ & $2.56 \pm 0.23^{\mathrm{b}}$ \\
FCR $3^{\text {rd }}$ week & $1.42 \pm 0.06^{\mathrm{a}}$ & $1.65 \pm 0.02^{\mathrm{a}}$ & $1.51 \pm 0.04^{\mathrm{a}}$ & $1.65 \pm 0.11^{\mathrm{a}}$ & $1.46 \pm 0.19^{\mathrm{a}}$ & $1.50 \pm 0.03^{\mathrm{a}}$ \\
Total FCR & $2.43 \pm 0.26^{\mathrm{ab}}$ & $2.59 \pm 0.31^{\mathrm{a}}$ & $2.15 \pm 0.07^{\mathrm{ab}}$ & $2.19 \pm 0.28^{\mathrm{ab}}$ & $2.22 \pm 0.17^{\mathrm{ab}}$ & $1.88 \pm 0.18^{\mathrm{b}}$ \\
BF\% & $0.14 \pm 0.04^{\mathrm{a}}$ & $0.08 \pm 0.02^{\mathrm{a}}$ & $0.11 \pm 0.02^{\mathrm{a}}$ & $0.09 \pm 0.02^{\mathrm{a}}$ & $0.11 \pm 0.02^{\mathrm{a}}$ & $0.10 \pm 0.02^{\mathrm{a}}$ \\
Thymus\% & $0.46 \pm 0.02^{\mathrm{a}}$ & $0.42 \pm 0.08^{\mathrm{a}}$ & $0.33 \pm 0.07^{\mathrm{a}}$ & $0.38 \pm 0.06^{\mathrm{a}}$ & $0.42 \pm 0.04^{\mathrm{a}}$ & $0.58 \pm 0.14^{\mathrm{a}}$ \\
Spleen\% & $0.09 \pm 0.00^{\mathrm{c}}$ & $0.13 \pm 0.01^{\mathrm{abc}}$ & $0.12 \pm 0.00^{\mathrm{abc}}$ & $0.15 \pm 0.03^{\mathrm{a}}$ & $0.10 \pm 0.01^{\mathrm{bc}}$ & $0.14 \pm 0.02^{\mathrm{ab}}$ \\
\hline
\end{tabular}

Duncan represents least significant differences between different groups at probability $\mathrm{P}<0.05$. Means with different superscripts $(\mathrm{a}, \mathrm{b}, \mathrm{c}, \mathrm{d})$ within a row are significantly different at $\mathrm{P}<0.05$. 
Effect of using synbiotics and essential oils on performance parameters and immune response of necrotic enteritis

Table 4: Effect of antibiotic, synbiotic and essential oils on humeral immune response to viral vaccines (means \pm SE).

\begin{tabular}{|c|c|c|c|c|c|c|c|}
\hline & & ABAC & SY & EO & SYEO & $\mathrm{NE}$ & $\mathrm{CN}$ \\
\hline \multirow[t]{2}{*}{ ND } & $3 \mathrm{~W}$ & $0.30 \pm 0.30^{\mathrm{ab}}$ & $0.00 \pm 0.00^{\mathrm{b}}$ & $1.11 \pm 0.56^{\mathrm{a}}$ & $1.10 \pm 0.20^{\mathrm{a}}$ & $0.00 \pm 0.00^{\mathrm{b}}$ & $0.00 \pm 0.00^{\mathrm{b}}$ \\
\hline & $5 \mathrm{~W}$ & $0.70 \pm 0.70^{\mathrm{a}}$ & $0.00 \pm 0.00^{\mathrm{a}}$ & $0.00 \pm 0.00^{\mathrm{a}}$ & $0.00 \pm 0.00^{\mathrm{a}}$ & $0.00 \pm 0.00^{\mathrm{a}}$ & $0.00 \pm 0.00^{\mathrm{a}}$ \\
\hline \multirow[t]{2}{*}{ AI } & $3 \mathrm{~W}$ & $0.30 \pm 0.30 \mathrm{bc}$ & $0.00 \pm 0.00 \mathrm{c}$ & $0.00 \pm 0.00 \mathrm{c}$ & $0.30 \pm 0.30 \mathrm{abc}$ & $0.67 \pm 0.12 \mathrm{ab}$ & $0.20 \pm 0.20 \mathrm{bc}$ \\
\hline & $5 \mathrm{~W}$ & $1.20 \pm 0.00 \mathrm{a}$ & $0.40 \pm 0.40 \mathrm{~b}$ & $1.42 \pm 0.27 \mathrm{a}$ & $0.30 \pm 0.30 \mathrm{~b}$ & $1.10 \pm 0.20 \mathrm{a}$ & $0.00 \pm 0.00 \mathrm{~b}$ \\
\hline \multirow[t]{2}{*}{ IB } & $3 \mathrm{~W}$ & $0.00 \pm 0.00 \mathrm{~b}$ & $4385.0 \pm 453.38 \mathrm{a}$ & $2543.3 \pm 21.18 \mathrm{~b}$ & $0.00 \pm 0.00 \mathrm{~b}$ & $117.00 \pm 8.88 \mathrm{~b}$ & $142.00 \pm 8.00 \mathrm{~b}$ \\
\hline & $5 \mathrm{~W}$ & $4344.0 \pm 446.77 \mathrm{c}$ & $13772 \pm 720.57 \mathrm{a}$ & $3594.0 \pm 162.26 \mathrm{c}$ & $3642.7 \pm 1102.29 \mathrm{c}$ & $9101.3 \pm 593.94 \mathrm{~b}$ & $0.00 \pm 0.00 \mathrm{~d}$ \\
\hline \multirow[t]{2}{*}{ IBD } & $3 \mathrm{~W}$ & $233.00 \pm 33.50 \mathrm{c}$ & $634.67 \pm 43.59 \mathrm{bc}$ & $808.33 \pm 95.13 \mathrm{ab}$ & $644.33 \pm 13.86 b c$ & $922.33 \pm 14.19 \mathrm{ab}$ & $244.33 \pm 244.33 \mathrm{c}$ \\
\hline & $5 \mathrm{~W}$ & $0.00 \pm 0.00^{\mathrm{c}}$ & $0.00 \pm 0.00^{\mathrm{c}}$ & $293.33 \pm 23.33^{\mathrm{a}}$ & $220.00 \pm 11.54^{b}$ & $0.00 \pm 0.00^{\mathrm{c}}$ & $0.00 \pm 0.00^{\mathrm{c}}$ \\
\hline
\end{tabular}

Duncan represents least significant differences between different groups at probability $\mathrm{P}<0.05$. Means with different superscripts $(\mathrm{a}, \mathrm{b}, \mathrm{c}, \mathrm{d})$ within a row are significantly different at $\mathrm{P}<0.05$.

*N.B.) Antibody titers against ND and AI vaccines were measured by HI test. Antibody titers against IB and IBD vaccines were measured by ELISA test.

Plate 1: Histopathological changes in bursa of Fabricius of euthanized chicks

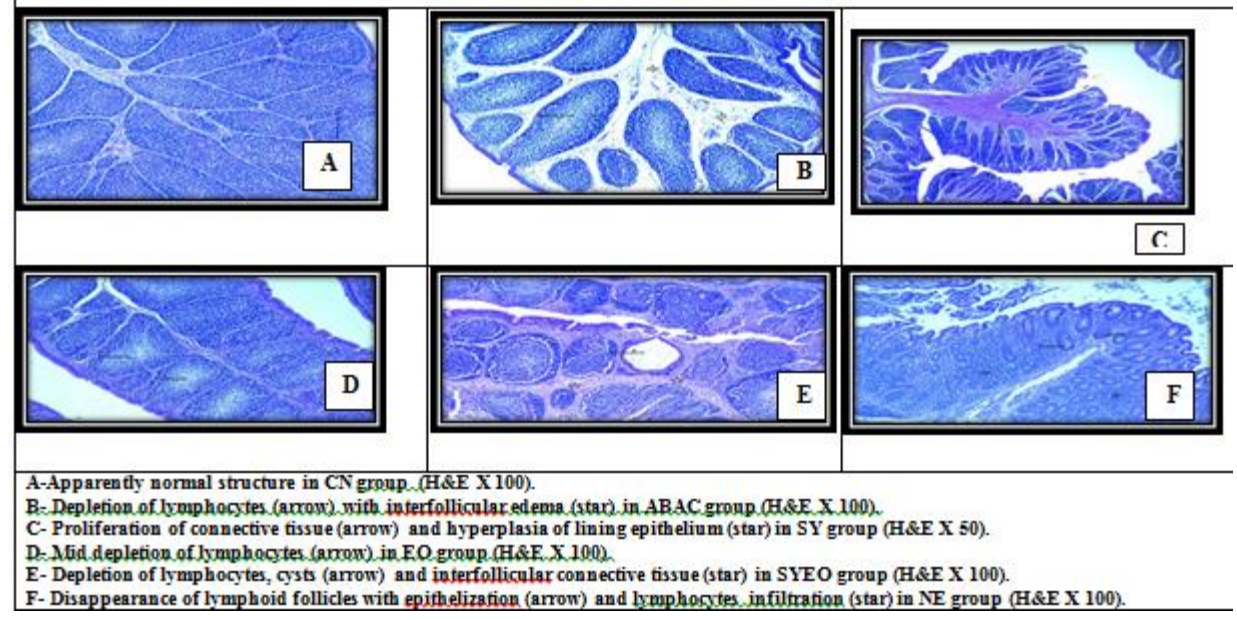

Plate 2: Hishological changes in thymus of euthanized chicks
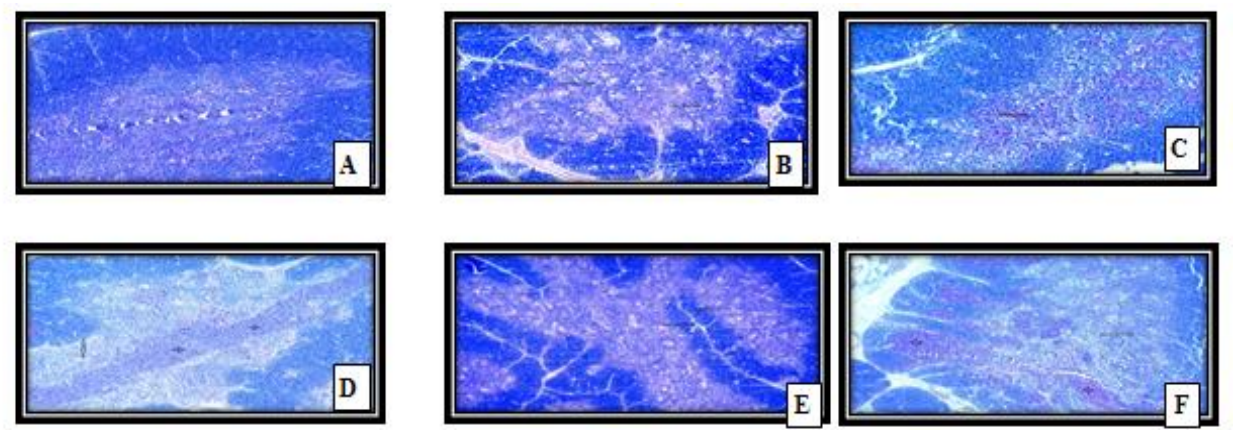

A-Apparently normal thymus in CN group. H\&F. $\mathrm{X} 1002$

B- Depletion of medullary thrmoctes(arrow) in ABAC group (H\&E X 50).

C. Focal hemonchage (ancow) in SY group (H\&E X 200),

D- Depletion of medullary thymocoter (arrow) and hemonhage (star) in EO group (H\&E X 50).

E- Serere depletion of med ullare thymogter. (axour) in SXEO group (H\&E X 50),

F- Depletion of thymocter (arrow) and hemorrhage (star) in $\mathrm{NE}$ group (H\&E X 50 ) 


\section{Discussion:}

The use of dietary additives as probiotics and phytobiotics are gaining momentum and paid an attention to be used as an alternative to antibiotic feed additives because of their beneficial effects on health of poultry as well as to avoid the hazards of continued using of antibiotics on human health.

Adding the EO alone or in combination with synbiotic has improved the total FCR in comparison with the NE and antibiotic treated groups while it did not have significant effect on feed intake. On the other hand, using the synbiotic did not enhance the aforementioned parameters in comparison with the positive control and ABAC groups. These results come along with those of Jerzsele et al., (2012) who found that using essential oils in diets of $C$. perfringens challenged broiler chicks has improved weight gain, while using probiotics (B. amyloliquefaciens spores) did not alleviate the drop in body weight gain associated with the NE challenge. The lake of efficiency on performance parameters when using biotic products with $C$. perfringens challenged birds was reported also by Shanmugasundaram and Selvarai (2013) and M.Sadeq et al., (2015). Contaray, Geier et al., (2010) reported positive impact of the probiotic based products on BW and mortality $\%$ of challenged broilers. The EO ,as type of phytobiotics, are able to improve the taste and feed palatability, stimulate the secretion of bile, mucus and saliva and improve the digestive enzymes activities as well as, they have antimicrobial activity against $C$. Perfringens and other intestinal pathogens (Alloui et al., 2014).

Using synbiotics in diets of vaccinated broilers improved the antibody titer to IB vaccine while it did not affect the immune response to ND, AI and IBD vaccines. The additive did not improve relative weight of $\mathrm{BF}$ and thymus but increased spleen weight. Silva et al., (2009) and Seidavi et al., (2016) agreed with our findings as they reported absence of obvious significance in the antibody titer against AI, ND and IBD vaccines as well as absence of effect on weight of BF and thymus in broiler fed probiotics, prebiotic or their combination. Moreover, Tolba et al., (2007) reported improvement of spleen weight in Fayoumi hens fed diets containing commercial probiotic. On the other hand, the essential oils helped in hindering the antibody titer decline against ND and IB at third week of experiment and improved the immune response to AI and IBD vaccines at $5^{\text {th }}$ week. EO did not affect weight of BF and thymus but increased spleen weight $(\mathrm{P}>0.05)$. The combination between synbiotics and $\mathrm{EO}$ showed to be effective in improving immune response to ND and IBD vaccination as well as significantly increasing the spleen weight. Sultan et al., (2017) and Chowdhury et al., (2018) agreed with our findings by reporting significant increase of antibody titer against ND and AI vaccination as well as absence of any significant effect on weight of the lymphoid organs (BF) when broiler chicks given herbal compound in feed or water $(\mathrm{P}<0.05)$. Contrary, Özek et al., (2011) found insignificant improvement in ELISA antibody titer $(\mathrm{P}>0.05)$ against IB and IBD vaccines when laying hens fed diets with essential oil. We attribute our results to presence of certain components in essential oils, which may bind to immunoglobulin $\mathrm{G}$ recceptors and stimulate the immune response as recorded by Nimmerjahn and Ravetch, (2010) and Ahmed et al., (2013). In addition, some plant bioactive compounds regulate expressions of various genes involved in immune response (Liu et al., 2014). The used biological treatments did not alleviate the histopathological changes in thymus and $\mathrm{BF}$ except for the synbiotic treatment, which showed milder lesions in BF, same as antibiotic treated birds, in comparison with NE group. These results disagreed with Madian and Abd El-Ghany (2006) as they reported that using antibiotic with vaccinated broilers showed severe histopathological changes in thymus and $\mathrm{BF}$, while using biotic preparations showed lesser damage in them.

\section{Conclusion}

The current study suggests that essential oils may be used as effective alternative to antibiotics in broiler rations to augment drawbacks of NE challenge on performance and enhance immune response of broiler chicks. As well as, offering the consumers with healthy poultry products, free from antibiotic residues.

\section{References:}

Ahmed, S.T., Hossain, M.E., Kim, G.M., Hwang, J.A., Ji, H., Yang, C.J. 2013. Effects of resveratrol and essential oils on growth performance immunity, digestibility and fecal microbial 
shedding in challenged piglets. AsianAustralas. J. Anim. Sci. 26, 683-690.

Alloui, M. N., Agabou, A. and Alloui, N. 2014. Application of herbs and phytogenic feed additives in poultry production-A Review. Global Journal of Animal Scientific Research, 2(3):234-243.

Andremont, A. 2000. Consequences of antibiotic therapy to the intestinal ecosystem. Ann. Fr. Anesth. Reanim., 19: 395-402.

Bancroft, J.D. Stevens, A. and Turner, D.R. 1996. Theory and practice of histopathological techniques. Fourth Ed. Churchil Livingstone, New York, London, San Francisco, Tokyo.

Chowdhury, S., Mandala, G., Patraa, A., Kumara, P., Samantab, I., Pradhanc, S., Chowdhurya, A., Mandala, G., Patraa, A., Kumara,P., Samantab, I., Pradhanc, S. and Samantad, A. 2018. Different essential oils in diets of broiler chickens: Gut microbes and morphology, immune response, and some blood profile and antioxidant enzymes. Animal Feed Science and Technology 236:39-47.

Dahiya, J.P., Wilkie, D.C., Van Kessel, A.G. and Drew M.D. 2006. Potential strategies for controlling necrotic enteritis in broiler chickens in postantibiotic era. Anim. Feed Sci. Technol,129: 60-88.

Duncan, D.B. 1955. Multiple range and multiple F tests. Biometrics 11:1-42.

Europe Union Commission 2005. Ban on antibiotics as growth promoters in animal feed enters into effect. Regulation 1831/2003/EC on additives for use in animal nutrition, replacing Directive 70/524/EEC on additives in feed-stuffs, Brussels, 22 December.

Fooks, L. J. and Gibson, G. R. 2002. Probiotics as modulators of the gut flora. British journal of nutrition, 88(1): 39-49.

Geier, M.S., Mikkelsen, L.L., Torok, V.A., Allison, G.E., Olnood, C.G., Boulianne, M., Hughe, R.J. and Choct,
M. 2010. Comparison of alternatives to in-feed antimicrobials for the prevention of clinical necrotic enteritis. Journal of Applied Microbiology, 109:1329-1338.

Gholamiandehkordi, A.R., Timbermont, L., Lanckriet, A., Van Den Broeck, W., Pedersen, K., Dewulf, J., Pasmans, F., Haesebrouck, F., Ducatelle, R. and Van Immerseel, F. 2007. Quantification of gut lesions in subclinical necrotic enteritis. Avian Pathol, 36:375-382.

Jayaraman, S., Thangave, G., Kurian, H., Mani, R., Mukkalil, R. and Chirakkal, H. 2013. Bacillus subtilis PB6 improves intestinal health of broiler chickens challenged with Clostridium perfringens-induced necrotic enteritis. Poultry Science 92:370-374.

Jensen, B.B. 1998. The impact of feed additives on the microbial ecology of the gut in young pigs.J.Anim.Feed Sci.,7: 45- 64.

Jerzsele, A., Szeker, K., Csizinszky, R., Gere, E., Jakab, C., Mallo, J. J. and Galfi, P. 2012. Efficacy of protected sodium butyrate, a protected blend of essential oils, their combination, and Bacillus amyloliquefaciens spore suspension against artificially induced necrotic enteritis in broilers. Poultry Science, 91 :837-843.

Khan, S.H. 2014. The use of green tea (Camellia sinensis) as a phytogenic substance in poultry diets. Journal of Veterinary Research 81(1): 1-8.

Kubkomawa, H.I., Nafarnda, D.W., Mukang, S.M., Tizhe, M.A., Tuakam, D.K., Shua, N.J., Ugwu, C.C., Opara, M.N., Neils, J.S., Okoli, I.C. 2013. Ethnoveterinary health management practices amongst livestock producers in Africa - A review. World J. Agri. Sci. 1(8):252-257.

Lambert, W. V., Ellis, N. R., Block, W. H. and Titus, H.W. 1936. The role of nutrition in genetics. American Research Society of Animal Production, 229:236.

Liu, Y., Song, M., Che, T.M., Lee, J.J., Bravo, D., Maddox, C.W., Pettigrew, J.E., 
2014. Dietary plant extracts modulate gene expression profile in ileal mucosa of weaned pigs after Escherichia coli infection. J. Anim. Sci. 92, 2050-2062.

Madian, K. and Abd El-Ghany, A. 2006. Study on the effects of prebiotic, synbiotic and probiotic as alternatives to antibiotic growth promoter, on the performance, intestinal colonization, humoral immune response and clinical serum chemistry of the broiler chickens. Proc. 3rd Inter Conf. Vet. Res. Div., Cairo, Egypt.

M'Sadeq, S.A., Wu, S.B., Choct, M., Forder, R., and Swick, R.A. 2015. Use of yeast cell wall extract as a tool to reduce the impact of necrotic enteritis in broilers. Poultry Science 94:898-905.

Mitsch, P., Zitterl-Eglseer, K. B., Gabler, C., Losa, R. and Zimpernik, I. 2004. The effect of two different blends of essential oil components on the proliferation of Clostridium perfringens in the intestines of broiler chicken. Poult. Sci., 83:669-675.

Nimmerjahn, F., Ravetch, J.V., 2010. Antibody-mediated modulation of immune responses. Immunolog. Rev. 236, 265-275.

National Research Council (NRC) 1994. Nutrient requirements of poultry. 9th Ed, Washington, DC National academy

OIE, 2012. Terrestrial Manual. Chapter 2. 3. 14. New castle disease.

Özek, K., Wellmann, K.T., Ertekin, B. and Tarım, B. 2011. Effects of dietary herbal essential oil mixture and organic acid preparation on laying traits, gastrointestinal tract characteristics, blood parameters and immune response of laying hens in a hot summer season. Journal of Animal and Feed Sciences, 20:575-586.

Seidavi, A., Dadashbeiki, M., Saraei, M.H.A. \& Hoven, R.V.; Carreira, R.P.; Laudadio, V.; and Tufarelli, V. 2016. Effects of dietary inclusion level of amixture of probiotic cultures and enzymes on broiler chickens immunity response.
Environ Sci Pollut Res, 24(5): 46374644.

Shanmugasundaram, R. and Selvarai, j. 2013. Effect of yeast cell product (CitriStim) supplementation on broiler performance and intestinal immune cell parameters during an experimental coccidial infection. Poultry Science, 92: 358-363.

Silva, V. K., Della Torre da Silva, J., Torres, K. A. A., de Faria Filho, D. E., Hirota Hada, F. and Barbosa de Moraes, V. M. 2009. Humoral immune response of broilers fed diets containing yeast extract and prebiotics in the prestarter phase and raised at different temperatures. J. Appl. Poult. Res. 18:530-540.

Sultan, R., Aslam, A., Saleem, G., Anjum, A., Krull, W., Kumosani, T. and Barbour, B. 2017. Studies on performance, immunity, and safety of broilers vaccinated with killed $\mathrm{H} 9 \mathrm{~N} 2$ vaccine and supplemented with essential oils of Mentofin $₫$ in drinking water. Intern J Appl Res Vet Med, Vol. 15, No. 2, 76-74.

Sun, X., McElroy, A., Webb, K. E., Sefton, Jr. A. E., Novak, C. 2005. Broiler performance and intestinal alterations when fed drug-free diets. Poultry Science, 84: 1294-1302.

Tolba, A.A.H., Wagdy, A.Z. and Shabaan, S.A.M. 2007. Improvement of Fayoumi laying hens performance under hot climate conditions. Egypt Poult. Sci. 27 (I): $1-20$.

Van Immerseel, F., De Buck, J., Pasmans, F., Huyghebaert, G., Haesebrouck, F., Ducatelle R. 2004. Clostridium perfringens in poultry: an emerging threat for animal and public health. Avian Pathol, 33:537-549.

Verma, J., johri, T.S., Swain, B.K. and Ameena, S. 2004. Effect of graded level of aflatoxin, ochratoxin and their combinations on the performance and immune response of broilers. British poultry science, 45 : 512- 